\title{
First record of Demicryptochironomus (Irmakia) neglectus Reiss, 1988 in Slovakia
}

\author{
Veronika Štillová ${ }^{1}$ and Soňa Ščerbáková ${ }^{2}$ \\ ${ }^{1}$ Department of Biology and Ecology, Matej Bel University, Tajovského 40, SK-974 01 Banská Bystrica, \\ Slovakia.E-mail: stillova93@gmail.com \\ ${ }^{2}$ Department of Hydrobiology, Microbiology and Ecotoxicology, Water Research Institute, Nábrežie arm. \\ Gen. L. Svobodu 5, SK-812 49 Bratislava 1, Slovakia.E-mail: sona.scerbakova@gmail.com
}

\begin{abstract}
Here, we present the first record of Demicryptochironomus (Irmakia) neglectus Reiss, 1988 in Slovakia. Samples were taken using the Chironomid Pupal Exuviae Technique (CPET) from two reservoirs. Two pupal exuviae (out of the 500 ind. collected) were recorded in Král'ová reservoir and in one individual was found in Síňava reservoir (out of the total 514 ind. collected). Since the CPET method mostly allows species level identification of chironomids, its usage is helpful in discovering the real chironomid diversity of Slovakia. Moreover, it helps to define ecological requirements of species we have little information about, such as the present one.
\end{abstract}

\section{Introduction}

The Chironomid Pupal Exuviae Technique (CPET; Wilson \& Ruse, 2005) as a method for assessing ecological quality of water reservoirs in Slovakia started in 2009. Since then, eight new chironomid species were recorded in Slovakia using the CPET technique within the national monitoring program (Ščerbáková \& Bitušík; 2013, 2015) confirming the usefulness of this method to identify chironomids in various aquatic ecosystems. This method greatly contributes, among other things, to the knowledge of the regional fauna. In the present paper we report the first record of Demicryptochironomus (Irmakia) neglectus for Slovakia from two reservoirs along with information on the environmental conditions of the habitat of occurrence.

\section{Material and methods}

Material was collected by drift sampling according to the Chironomid Pupal Exuviae Technique (Wilson $\&$ Ruse, 2005) and preserved with 75\% ethanol. In laboratory around 500 exuviae were picked from a total amount of sampled euviae, mounted on permanent microscopic slides and identified using Langton and Wisser (2003). Sampling and processing of material was in accordance with the European standard (SFSEN15196:2006). Material is deposited at the Department of Hydrobiology, Microbiology and Ecotoxicology, Water Research Institute in Bratislava.

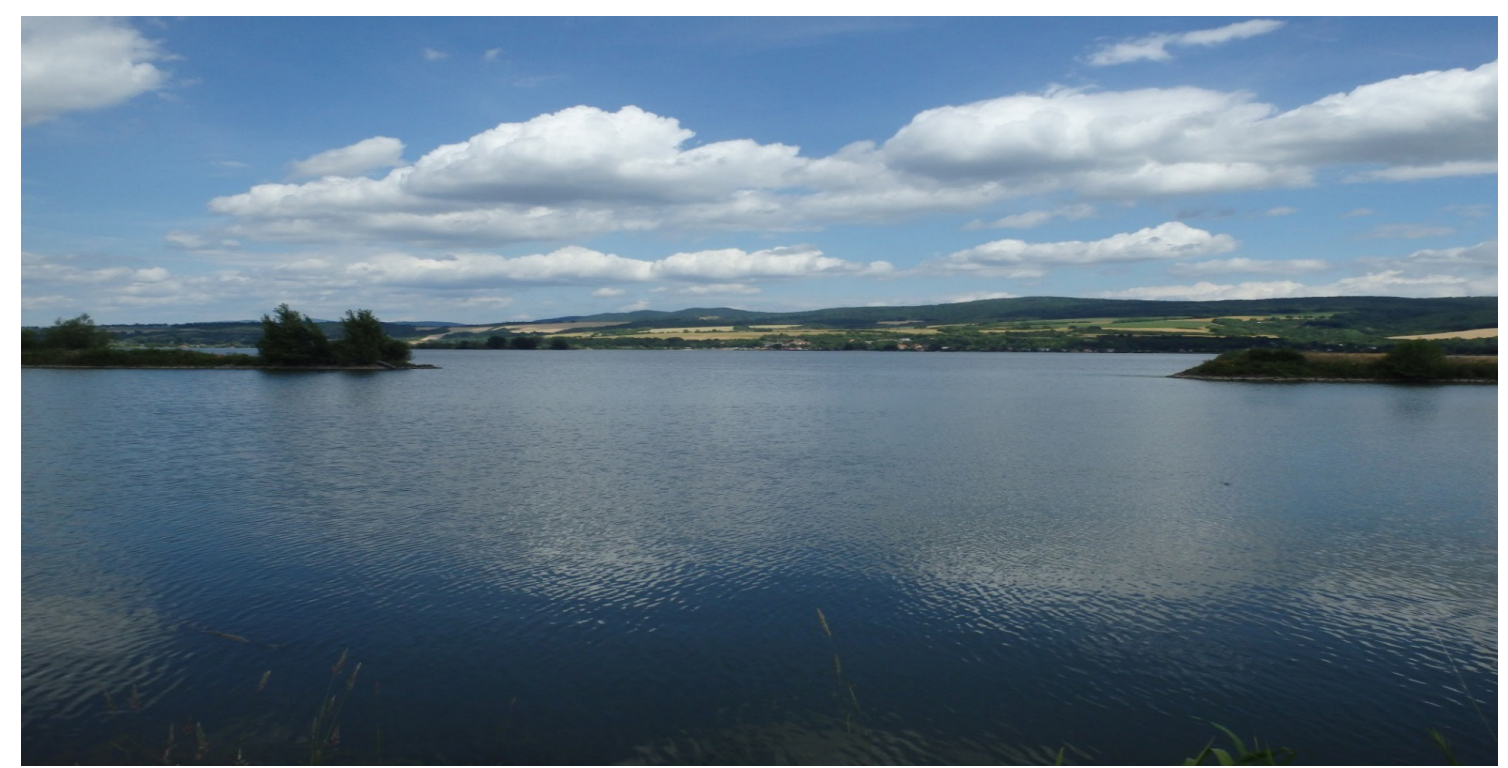

Figure 1. Water reservoir Síňava. Photo S. Ščerbáková 03.08.2015. 


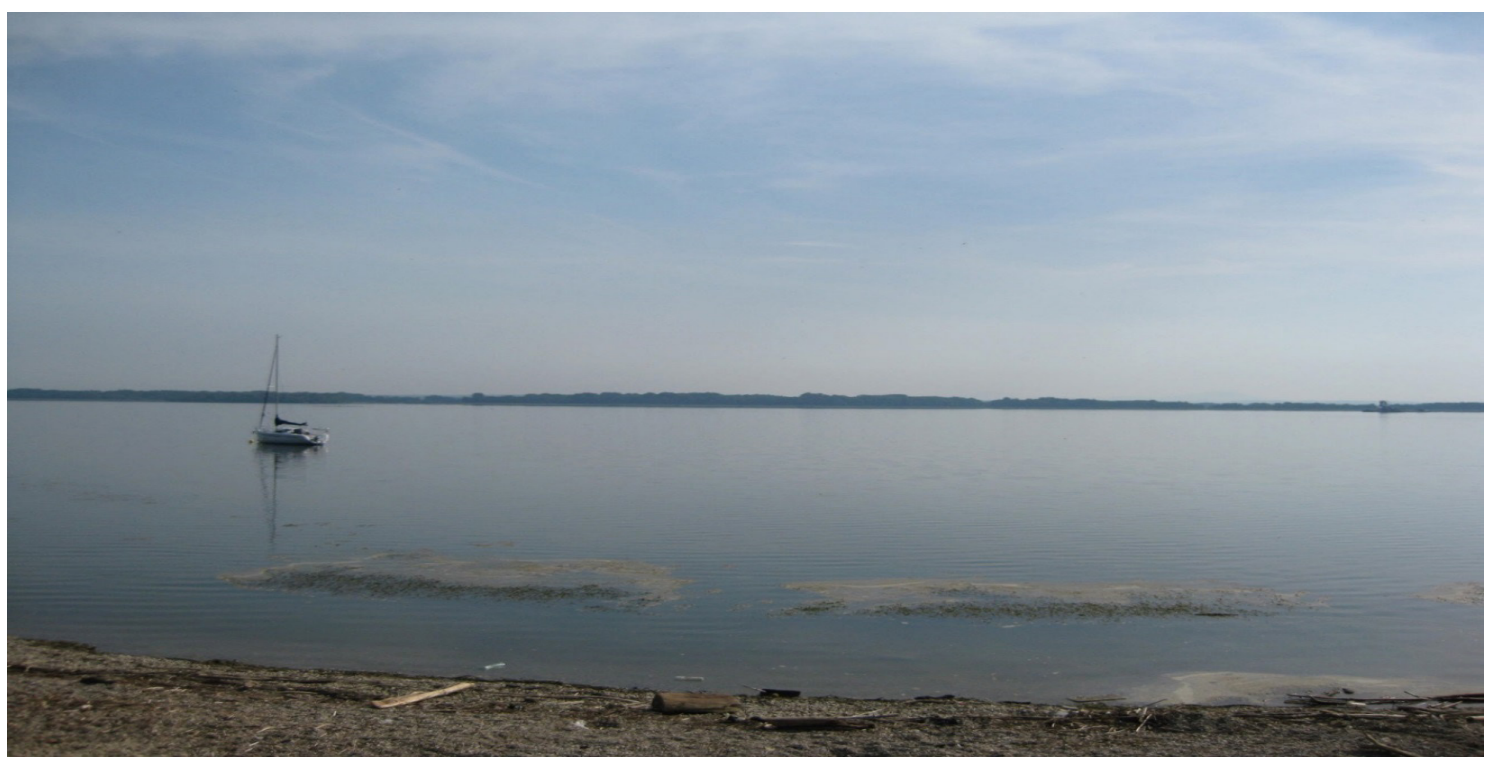

Figure 2. Water reservoir Král'ová. Photo S. Ščerbáková 19.06.2013.

Samples were taken from two water reservoirs - Síňava and Králová (Figs. 1, 2), both situated at the lower stretch of the River Váh. These two reservoirs represent the lowermost situated reservoirs built within the chain of hydropower plants on the River Váh. The distance between the two studied reservoirs is $38.6 \mathrm{~km}$. Details of hydromorphological conditions and measured physicochemical parameters from both reservoirs collected in the year of findings are presented in Table 1.

Table 1. Hydromorphological and physicochemical characteristics of the studied water reservoirs (WR).

\begin{tabular}{|c|c|c|c|}
\hline Variable/site name & Unit & WR Král'ová & WR SÍňava \\
\hline & & $48^{\circ} 12^{\prime} 33.15^{\prime \prime} \mathrm{N}$ & $48^{\circ} 33^{\prime} 17.1 " \mathrm{~N}$ \\
\hline Coordinates & & $17^{\circ} 48^{\prime} 03.18^{\prime \prime} \mathrm{E}$ & $17^{\circ} 49^{\prime} 30.6^{\prime \prime} \mathrm{E}$ \\
\hline Altitude & m a.s. 1. & 124 & 158 \\
\hline Depth $\varnothing$ & $\mathrm{m}$ & 6.00 & 3.10 \\
\hline Area & $10^{6} \mathrm{~m}^{2}$ & 10.90 & 4.10 \\
\hline Max. volume & $10^{6} \mathrm{~m}^{3}$ & 65.50 & 12.50 \\
\hline Ret. time & day & 1.7 & 0.3 \\
\hline \multicolumn{4}{|l|}{ Water chemistry } \\
\hline Oxygen & mg. $1^{-1}$ & 9.00 & 7.62 \\
\hline $\mathrm{pH}$ & - & 7.79 & 8.03 \\
\hline Temperature & ${ }^{\circ} \mathrm{C}$ & 18.03 & 19.27 \\
\hline Conductivity & $\mathrm{mS} . \mathrm{m}^{-1}$ & 37.53 & 40.34 \\
\hline $\mathrm{NH}^{4-\mathrm{N}}$ & $\operatorname{mg} .1^{-1}$ & 0.054 & 0.074 \\
\hline $\mathrm{NO}^{3-} \mathrm{N}$ & mg..$^{-1}$ & 0.984 & 0.960 \\
\hline $\mathrm{N}$ total & mg. $1^{-1}$ & 1.436 & 1.510 \\
\hline P total & mg. $1^{-1}$ & 0.062 & 0.058 \\
\hline $\mathrm{PO}^{4-\mathrm{P}}$ & mg. $1^{-1}$ & 0.036 & 0.036 \\
\hline
\end{tabular}




\section{Results}

The following specimens of Demicryptochironomus (Irmakia) neglectus Reiss, 1988 (Chironominae, Chironomini) were found:

Král'ová water reservoir - 2 pupal exuviae (from total number of 500 individuals), 19. 6. 2013, coll. S. Ščerbáková, det. S. Ščerbáková; Síňava water reservoir - 1 pupal exuvia (from total number of 514 individuals), 3. 8. 2015, coll. S. Ščerbáková, det. V. Štillová (Fig. 3).

Demicryptochironomus (Irmakia) neglectus is a chironomid with distribution in Western Europe (Austria, Britain, Finland, French mainland, Germany, Ireland, Switzerland) and in East Palearctic (Spies and Sæther, 2013). Adults and exuviae were collected in and along streams and rivers in the alpine region, the Black Forest and the British Isles (as Pe1) (Moller Pillot, 2009 and references therein), but also in China (Yan et al., 2005).

In general, larvae of the genus Demicryptochironomus Lenz, 1941 are tolerant to organic pollution - CPET tolerant group D (Wilson \& Ruse, 2005). They occur in lakes and rivers with sandy or muddy substrate. They are predatory and feeding especially on oligochaetes (Pinder \& Reiss, 1983).

Exuviae identified by Langton (1991) have been described and illustrated in Pinder \& Reiss (1986) as Chironomini Genus D. The larval stage has not yet been described.

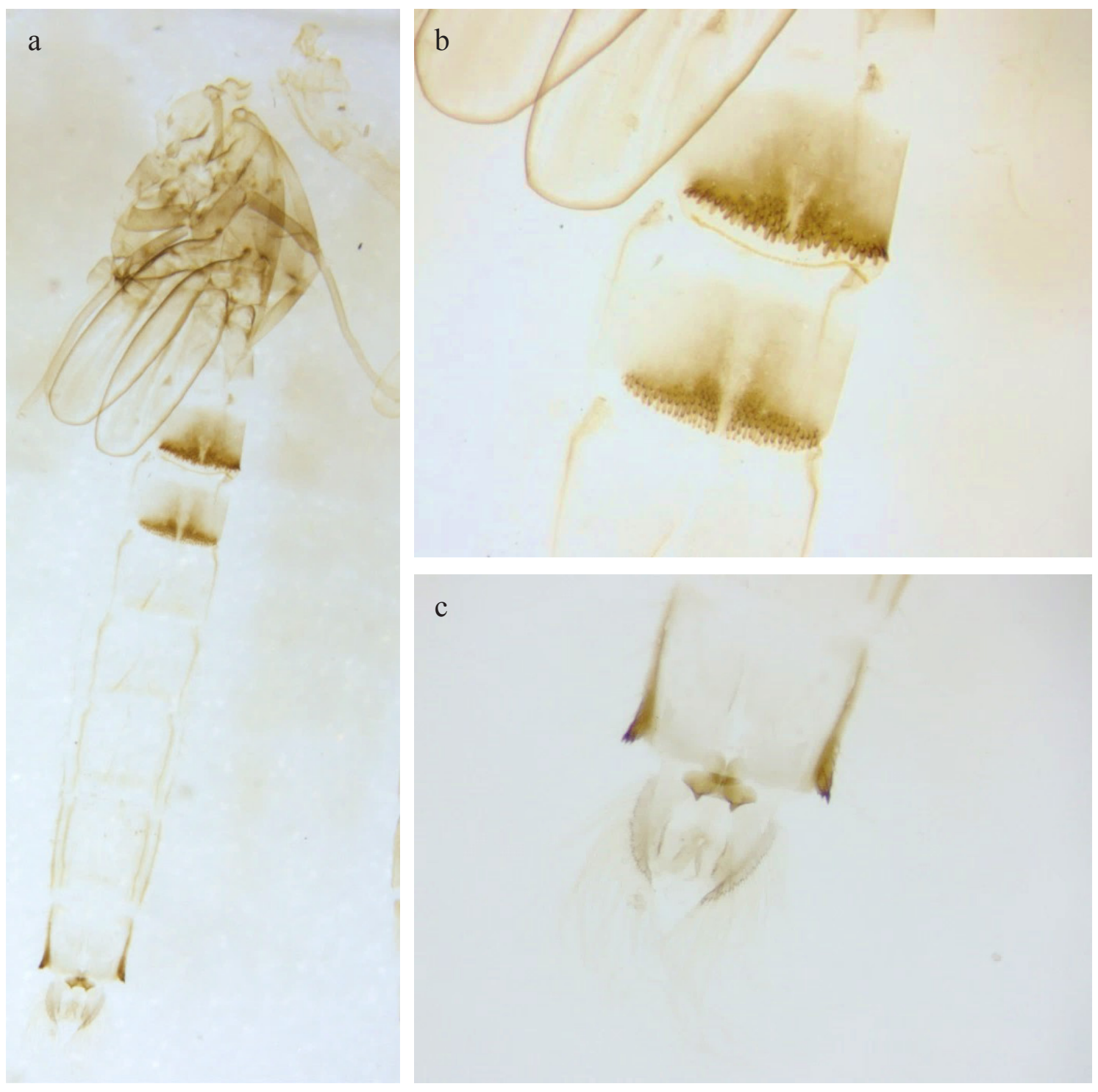

Figure 3. Photos of the exuvia of Demicryptochironomus (Irmakia) neglectus. a) pupal exuvia, b) $2^{\text {nd }}$ and $3^{\text {rd }}$ segment, c) anal combs of the $8^{\text {th }}$ segment. Photo S. Ščerbáková. 


\section{Acknowledgements}

Financial supports from the EU Cohesion Funds within the project Monitoring and assessment of water body status (No. 24110110158, 2012-2015 Phase II) and by grant VEGA No 1/0664/15 are acknowledged. We are grateful to Ladislav Hamerlík and Peter Bitušík, Department of Biology and Ecology, Matej Bel University for their valuable comments to the manuscript.

\section{References}

Langton, P.H. 1991. A key to pupal exuviae of West Palaearctic Chironomidae. Private publication. St. Felix Road, Ramsey Forty Foot, Huntingdon, Cambridgeshire. England, 386 p.

Langton, P.H. and Visser, H. 2003. Chironomidae exuviae. A key to pupal exuviae of the West Palaearctic Region. Interactive Identification System for the Europaean Limnofauna (IISEL). World Biodiversity Database, CD-ROM Series.

Yan, Ch., Tang, H., Wang, X. 2005. Demicryptochironomus Lenz from China (Diptera: Chironomidae). Zootaxa 910: 1-31.

Moller Pillot, H.K.M. 2009. Chironomidae Larvae. Biology and Ecology of the Chironomini. KNNV Publishing, Zeist, The Netherlands, $270 \mathrm{p}$.

Pinder, L.C.V. and Reiss, F. 1983. The larvae of Chironominae (Diptera: Chironomidae) of the Holarctic region - Keys and diagnoses. - Entomologica Scandinavica Supplement 19: 293-435.

Pinder, L.C.V. and Reiss, F. 1986. The pupae of Chironominae (Diptera: Chironomidae) of the Holarctic region - Keys and diagnoses. - Entomologica Scandinavica Supplement 28: 299-456.

EN 15196:2006. Water quality. Guidance on sampling and processing of the pupal exuviae of Chironomidae (Order Diptera) for ecological assessment: $11 \mathrm{p}$.

Ščerbáková, S. and Bitušík, P. 2013. New records of Chironomidae (Diptera) for Slovakia from water reservoirs. - Lauterbornia 76: 25-28.

Ščerbáková, S. and Bitušík, P. 2015. New records of chironomids (Chironomidae: Diptera) from Slovakia. - Acta Musei Silesiae Scientiae Naturales 64: 127-129.

SFS-EN 15196:2006. 2006. Water quality. - Guidance on sampling and processing of the pupal exuviae of Chironomidae (Order Diptera) for ecological assessment, pp. 1-13.

Wilson, S.R. and Ruse, L.P. 2005. A guide to the identification of genera of chironomid pupal exuviae occurring in Britain and Ireland and their use in monitoring lotic and lentic freshwaters. Special Publication no.13. Freshwater Biological Association Scientific Publ., Windermere: 176 p.

Spies, M. and Sæther, O.A. 2013. Fauna Europaea: Chironomidae. In Pape, T. and Beuk, P. (Eds.): Fauna Europaea: Diptera, Nematocera. Fauna Europaea version 2018.08, http://www.faunaeur.org.

Article submitted 19. February 2019, accepted by Barbara Hayford 24. April 2019, published 07. May 2019. 